\title{
Preventing Authorization Deviation of the Minister of Law and Human Rights to Political Parties in Indonesia through a one Roof Political Judging System
}

\author{
Tri Cahya Indra Permana ${ }^{1}$, Maftuh Effendi ${ }^{2}$, Oki Hajiansyah Wahab ${ }^{3} \&$ HS Tisnanta ${ }^{4}$ \\ ${ }^{1}$ Ph.d Student, Diponegoro University, Indonesia \\ ${ }^{2}$ Judge at Indonesian Supreme Court, Indonesia \\ ${ }^{3}$ Faculty of Law, University of Muhammadiyah Metro, Indonesia \\ ${ }^{4}$ Faculty of Law, University of Lampung, Indonesia \\ Correspondence: Oki Hajiansyah Wahab, Faculty of Law, University of Muhammadiyah Metro, Jalan K.H \\ Dewantara No. 116, Metro Pusat, Iringmulyo, Metro Tim., Kota Metro, Lampung 34125, Indonesia. Tel: \\ 0725-42445. E-mail: journalsubmit1@gmail.com
}

\author{
Received: March 17, $2018 \quad$ Accepted: April 4, $2018 \quad$ Online Published: May 31, 2018 \\ doi:10.5539/jpl.v11n2p73 URL: https://doi.org/10.5539/jpl.v11n2p73
}

\begin{abstract}
Law Number 31 of 2002 regarding Political Parties provides authority to the Minister of Law and Human Rights to register changes in the leadership of political parties was previously intended as a state administrator in the field of law and politics. The problem arises when the authority given in 2002 slowly shifted to become a government tool to obtain the support of political parties which is very dangerous for democracy and parties' independency. Settlement of political parties' leadership conflict is an integral part of the registration of political parties' leadership therefore an ideal dispute settlement model is needed. This paper is the result of a research on the Court judgments in the dispute of political parties' leadership. Ultimately this paper offers a One Roof Political Judgment Concept where one justice agency is empowered with an overall authority starting from the authority to examine the properness of the political party leadership at the central level and the Official decision regarding changes in the political party's leadership at the central level by Bawaslu. During all this time the General Election Supervisory Agency (Bawaslu) itself has acted as quasi justice given the authority to adjudicate all issues of the general election involving political parties. Bawaslu itself consist of professionals in the field of general election which are not affiliated to the political parties and controlled by the Election Advisory Board (DKPP). Through this model Political parties, KPU and Bawaslu shall become a sub-sub system of the political justice system in Indonesia.
\end{abstract}

Keywords: leadership registration, dispute settlement, political party

\section{Introduction}

The existence of political parties (political parties) is one indicator of the progress of democracy. The Indonesian state administration system has already established political parties in the law. However, the many differences of interests within the party itself often lead to internal party divisions. One of the most frequent internal party conflicts in Indonesia over the last five years is related to the stewardship of political parties and their registration.

Changes in the formation of a Political Party's leadership at the national level must be registered with the Ministry of Law and Human Rights (Menkum HAM) as of the promulgation of Law Number 31 of 2002 regarding Political Parties at the earliest 7 (seven) days and latest 30 (thirty) days as of the date of such changes in leadership. Registration of the political party at the central level is intended to verify who of the political party's leadership at the central level including their position and duties and functions, who is responsible on the political party's activities, who can represent the political party inside and outside the court and ensure that there is no dualism in the leadership.

In the registration of a political party's leadership changes there are guidelines which must be complied by the Menkum HAM such as: Firstly, the authority of such Menkum HAM can be conducted in a normal situation 
where there is no conflict among the political party's leadership concerned. If there is still a conflict, the Menkum HAM is prohibited to issue the registration decision on the changes in such political party's leadership until the conflict is resolved or there is a legal judgment with a fixed legal force. Such prohibition beside being a universal principle for any entity or official, as regulated in Law Number 2 of 2008 regarding Political Parties. ${ }^{2}$

Secondly, the authority of the Menkum HAM to register the changes in the political party's leadership is declarative in nature or just a ratification after going through a review process which resolved the decision which is constitutive in nature i.e. participant of the National Assembly/Congress//Muktamar contained in a notarial deed or if there is conflict in the leadership the decision which is constitutive in nature is under the party' Mahkamah Partai (Advisory Board) decision or a decision of a justice agency with a legal fix power. In other words, the declarative authority of the Menkum HAM is only a copy paste authority of the decision of the participant of the National Assembly/Congress/Muktamar, decision of the Political Party Mahkamah (Advisory Board) or the adjudication of a justice agency with a fix legal power stating the validity of the Political Party at the central level. The declarative nature, however, is relative as the Minister of Law and Human Rights also has the authority to assess the requirements to obtain ratification of a political party's leadership changes registration.

Thirdly, such authority of the Menkum HAM is passive in nature meaning that the Minister must await an application from the Political Party's leadership concerned. In A contrario the Minister of Law and Human Rights may not actively notify requesting the political party's leadership to immediately propose a registration application for the changes in the political party's leadership as such matter may indicate the choosing of sides. If, however, the request of the registration is already submitted on the initiative of the concerned Political Party's leadership and there is a still incomplete document requirement, of course the Menkum HAM must be active to request such document incompleteness requirements as a realization of the precise and prudential principles of good governance.

Fourth, the authority of the Menkum HAM is limited by time and cannot therefore delay the time to issue a decision letter for the Political Party's leadership at the central level which is at the latest 7 (seven) days as of the receipt of the requirements".

An issue which often arises related to this Menkum HAM authority itself is when such authority slowly shifts to become a government tool to obtain the support of a Political Party. This may occur when the main function of the Menkum HAM towards the Political Party which previously only as state administrator in the field of law becomes a power tool. This paper applied the normative approach on court decisions related to the issues which have already fixed legal power.

Theoretically law as a political product so that every legal product will be determined by the balance of forces or political configuration that gave birth to it. Every legal product is a product of political decisions so that law can be seen as a crystallization of political thoughts interacting among politicians. The reality of law is often determined by the underlying political configuration (Mahfud MD, 2006: 65).

\section{Result and Discussions}

According to Daniel S. Lev, the conception and structure of political power is crucial in the legal process itself. The law is at least always a political tool, and that the place of law within the state depends on the balance of politics, the definition of power, the evolution of political, economic, social, and so on (Daniel S. Lev 1990: xii).Political power itself is interpreted as the ability to influence the general policy (government) both the formation and the consequences, in accordance with the interests of the holder of power.

In practice the handling of a request for a decision of the Menkum HAM of Political Parties which are already or starting to be involved in internal leadership dispute as detailed above, there are several facts as follows: Firstly, at the time when the Menkum HAM was held by Hamid Awaluddin between 2005-2006, there was a conflict of leadership in the PKB Political Party (Nation Awakening Party). At that time the Menkum HAM besides referring to the Political Party Laws also requested a fatwa from the Supreme Court regarding the attitude it must take related to two requests from two conflicting factions in the PKB. Further to it the Menkum HAM issued a decision letter regarding the formation of the leadership for both conflicting factions while waiting for the conflict to be resolve by the court. After the leadership conflict obtained a judgement with fixed legal power the Menkum HAM issued the decision of the Menkum HAM regarding cancelation of the leadership decision letter pronounced lost by the court.

Secondly, at the time when the Menkum HAM was held by Mohammad Andi Mattalata in 2008 there was again a conflict of leadership in the Partai Kebangkitan Bangsa (PKB) and the Menkum HAM at that time held fast to the Political Party Laws by adhering to the judgement of both the State Administrative Court and the District 
Court.

Thirdly, at the time that the Menkum HAM was held by Mr. Patrialis Akbar in 2010 there was a conflict of leadership in the Partai Peduli Rakyat Nasional (PPRN) and the Menkum HAM attitude at that time also followed the guidelines existing in the Political Party Laws by not issuing any decision letter as there were 2 (two) request from two conflicting factions, and therefore at that time the Menkum HAM was complaint to the State Administrative Court with a Negative Fictive Law construction but the Menkum Ham stance was considered right by the Court.

Fourthly, at that time that the Menkum HAM was held by Mr. Yasona H. Laoly starting from 2014 until 2018 there was several conflicts in Political Parties, PPP, Partai Golkar, PKPI and Partai Hanura. The Menkum HAM attitude against those four rifts in the conflicting parties is always to issue a decision letter of the Menkum HAM regarding the formation of the Political Party's leadership at the central level although the conflict was not yet solved and always issued decision letters for the Political Party's leadership supporting the government. This attitude of the Menkum HAM was always complained in the State Administrative Court and always lost. ${ }^{3}$

The Jakarta State Administrative Court decision backed up by the Decision of the Republic Indonesia Supreme Court in case Number 490/K/TUN/2015 in the conflict between the Golkar Party as plaintive versus Menkum HAM as defendant stated that the Menkum HAM action, issuing decision letter regarding the leadership at the time that such Political Party's leadership was still in dispute is a government intervention to the internal problem of the Political Party in disguise of officiating.

The functional shift of the Menkum HAM against political parties from previously only as state administrator in the field of law to become a power tool is due to several matters:

a. And effort to save the government's programs needed voting support in the parliament so that political parties in the position as "opposition" and in the state of management conflict become a sitting duck to be drawn into the government side with the compensation of the decision letter of the Menkum HAM regarding the political party's leadership.

b. The party's system in Indonesia which is multiparty and does not adhere to a permanent coalition is vulnerable to intervention by the Menkum HAM.

c. The praesumptio iustae causa principle of a decision letter is always deemed correct before being canceled by a Court, while the process of judging the Menkum HAM is always lengthy

Based on such above review, the Menkum HAM has several times distorted its authority and such matter is very dangerous for the democracy life and independence of Political Parties, therefore such authority of the Menkum HAM is not appropriate anymore to be maintained and must be assigned to other more appropriate state institution such as the KPU (General Election Commission).

The General Election Commission as an Independent State Institute is deemed to be more appropriate to be given the authority to register changes in a Political Party's leadership formation at the central level due to several reasons:

a. The KPU is an Independent state institution which is not in one of the executive, legislative, or judicative center.

b. The members/commissioners are not partisan.

c. The taking of resolutions and its leadership is collegial collective in nature.

d. The task and functions are related to Political Parties.

e. There is a DKPP (Election Advisory Board) supervising the KPU.

The central level political party's leadership conflict settlement model currently in force is proved not able to resolve the conflict leading to a positive authority between the District court and the State Administrative Court ultimately leading to a decision disparity and legal uncertainty. ${ }^{4}$

Resolving a political party's leadership dispute is in principal also an inseparable part with the registration of the political party's leadership therefore an ideal management dispute settlement model is needed. To reach a more effective and efficient settlement of a Political Party's leadership dispute there is no need for a legal effort through the Party Mahkamah as it has been proven that the Party Mahkamah is not able to settle a Political Party's leadership dispute at the central level.

Law and politics are difficult to separate as Curzon (1974: 44) argues that "The close connections between law and politics, between legal principles and the institutions of the law, between political ideologies and government 
institutions are obvious...".Nevertheless the authors view that even though a government wants to use the rules and powers for the achievement of political goals, the courts are still expected to stay away from political forum controversies.

Concerning democracy and constitutionalism Philip Pettit offers a strategy of constitutional provision (Pettit, 1999 : 67). According to it, the strategy of stipulating constitutional provisions seeks to eliminate or reduce domination not by making possibilities for the dominated groups to defend themselves against interference or to impede arbitrary interference, but rather to introduce a constitutional authority to the situation of domination relations.

The legal arrangement for the settlement of political party disputes is intended to simplify the procedure of litigation and to establish a strong and independent party system. Thus, it is expected that the future of democracy will proceed well and if dispute can be resolved through a fast, costly and transparent judicial process. The One Roof Political Judging System Concept is that one justice institution is given an overall authority starting from the authority to test the validity of the Political Party's leadership at the central level through testing the official resolution letter regarding the changes to the formation of the Political Party's leadership at the central level which has four alternatives i.e. District Court (PN), State Administrative Court (PTUN), Constitutional Court (MK) or Bawaslu.

The General Election Supervisory Board (Bawaslu) is deemed to be more proper to be given the authority to judge the Political Party's leadership dispute as during all this time it has acted as a quasi-court with the authority to adjudicate all issues in the general meeting covering political parties. Therefore, Political Parties, KPU and Bawaslu is a sub-sub system of the Political Court system in Indonesia. Another reason is that the members of the Bawaslu consist of professionals in the field of election which are not affiliated to any Political Party and the existence of the DKPP which has the authority to supervise the implementation of the ethic code of the Bawaslu members.

\section{Conclusions}

The One Roof Political Judging System Concept is offered as one of the justice agency given the overall authority starting from the authority to test the validity of the Political Party's leadership at the central level through testing the official resolution letter regarding the changes to the formation of the Political Party's leadership at the central level During all this time The General Meeting Supervisory Board (Bawaslu) itself has been acting as a quasi court authorized to judge all general election issues involving Political Parties. Bawaslu itself consist of respective professionals in their field of general election which are not affiliated to any Political Party and supervised by the DKPP which has also the authority to supervise the implementation of the code of ethics of the members of the Bawaslu. Further to this concept proposal a special procedural law is necessary based on the Bawaslu regulation regarding absolute competence, procedure of complaint registration, procedure law regarding Political Party's leadership dispute including its execution so that the dispute settlement shall be fair, effective and efficient.

The Researcher forward a suggestion for the KPU nomenclature to be changed into KP4U (Political Party and General Election Registration Commission) while the nomenclature BAWASLU is change into BAWAS P4U (Supervisory Agency on Political Party and General Election Registration).

\section{Acknowledgement}

The writer wishes to extend his gratitude to Prof. Dr Yos Johan Utama, Prof. Dr Yusril Ihza Mahendra and Dr. Supandi on their various suggestion on the writing of this paper.

\section{References}

Decision Mahkamah Syariah Dewan Pimpinan Pusat Partai Persatuan Pembangunan Nomor: 49/PIP/MP-DPP.PPP/2014 dated 11 October 2014.

Decision of the Golkar Party Mahkamah Number 01/PI-GOLKAR/II/2015, Number 02/PI-GOLKAR/II/2015, and Number 03/PI-GOLKAR/II/2015 dated 3 March 2015.

Decision PTUN Jakarta Number : 111/G/2008/PTUN.JKT dated 18 September 2008.

Decision PTUN Jakarta Number : 169/G/2010/PTUN.JKT dated 3 March 2011.

Decision PTUN Jakarta Number : 217/G/2014/PTUN.JKT dated 25 February 2015.

Decision PTUN Jakarta Number : 62/G/2015/PTUN.JKT dated 18 May 2015.

Decision PTUN Jakarta Number : 91/G/2010/PTUN.JKT dated 1 November 2010. 
Decision PTUN Jakarta Number: 308/G/2016/PTUN.JKT dated 21 June 2017.

LB, Curzon. (1979). Jurisprudence (Handbook Series). Macdonald \& Evans Ltd.

Lev, S. D. (1990). Hukum dan Politik di Indonesia, Kesinambungan dan Perubahan. LP3ES, Jakarta, Indonesia.

Mahfud MD, Moh. (2006). Membangun Politik Hukum, Menegakkan Konstitusi. Pustaka LP3ES, Jakarta, Indonesia.

Pettit, P. (1999). Republicanism: A Theory of Freedom and Government. Oxford: Oxford University Press. https://doi.org/10.1093/0198296428.001.0001

\section{Copyrights}

Copyright for this article is retained by the author(s), with first publication rights granted to the journal.

This is an open-access article distributed under the terms and conditions of the Creative Commons Attribution license (http://creativecommons.org/licenses/by/4.0/). 